\title{
Original article: \\ Optimal Use of the Forum to Develop Problem-Based Learning: Effective Use of Cyber space in a Holistic Process \\ Mosalanejad $L^{1}$, Raofi $R^{2}$, Montaseri $M A^{3}$, Abdollahifard $S^{4}$
}

\begin{abstract}
Absruct:
Introduction: Many medical schools have introduced PBL into their curricula because of the potential advantages for students' learning over traditional lecture based curricula. Integration of online discussion forums could help students, PBL and the curriculum. The aim of this article is the use of the Forum to Develop Problem-Based Learning as a Cyberspace in a Holistic Process and the investigating the effect of this program on students' satisfaction and students' cognitive competence. Methodology: For each curriculum used a discussion forum (DF) was created with 90 student and 8 tutors. Using forum for problem based learning- virtual quiz and virtual round develop and design to develop problem based learning and the best use of virtual space to promote teaching and learning also best use of technology in teaching as a new method. Results: Included: reforming and finalizing learning objectives, posting the concept map constructed in the face-to-face session and questioning, encouraging and motivating each other. In addition, posts included tutors' feedback and redirection. Conclusions: Blending e-learning with conventional PBL may help overcome student-perceived shortcomings of conventional PBL and improve the learning experience, making learning more interactive and interesting.
\end{abstract}

Keywords: Cyberspace; forum; problem based learning; students satisfaction; cognitive competence

Bangladesh Journal of Medical Science Vol. 16 No. 04 October'17. Page : 564-571

\section{Introduction}

In traditional educational models, learning usually requires the presence in a particular place and at certain hours. So that if a student is not present at a certain time in the classroom or due to a variety of other reasons, his presence in class is merely a physical presence, most likely he will face with problems in learning the lesson topics. And this has been always one of the barriers to learning in traditional education. Technologies have the potential to liberate education from the bondage of time and place. In fact, the class content, with the way that it is supposed to be in class, is placed within an interactive system like forums. In this way the student can learn the scientific subjects anywhere and when it is appropriate. Since there is the possibility of questions and answers in forums, students' questions will not remain unanswered and wherever there was ambiguity, teachers or other members will exchange their opinions. This in turn helps synergy of scientific information very much. Forums and other similar technologies such as blogs and other asynchronous media, provide learners with enough time to reflect on and he can read the content with the speed at which is appropriate for him, without any stress and anxiety, and learn to solve scientific problems ${ }^{1-3}$. Forums are one of the tools for Asynchronous communication in e-learning systems that are based on the research social model of Garrison and Anderson. The proper use of these tools helps to strengthen research, cognitive, learning and social skills. Besides enhancing learning different topics, forums strengthen high levels of cognitive skills, social capabilities such as how to communicate and negotiate, and research and writing skills in

1. Leili Mosalanejad, Associated Professor, Medical education center, Jahrom University of Medical Sciences, Jahrom , Iran

2. Rahim Raofi, Associated professor, Infectious Department, Jahrom University of Medical Sciences, Jahrom, Iran

3. Mohammad Ali Montaseri, Nursing Depatment, Jahrom University of Medical Sciences, Jahrom , Iran

4. Saeed Abdollahifard, Medical Student, Student Research Committee. Shiraz University of Medical Sciences, Shiraz, iran

Correspondence to: Leili Mosalanejad: Associated professor, Medical education center, Jahrom University of Medical Sciences, Jahrom, Iran. Email: saedparsa2012@gmail.com, Mosallanejad@jums.ac.ir 
students. But in terms of teachers, forums on the development of cognitive skills, and competencies collaborative learning things do not work ${ }^{4,5}$. The use of technology in education and its application in education, learning and students' evaluation, is among the new educational strategies in today's world. In an e-learning system, virtual forums are among those parts that have obviously changed the one-sided teacher-student relationship and promote it from the level of teaching - learning to the level of learner ${ }^{6-8}$. On the other hand, in all universities adviser teacher training program with the aim of educational promotion of students is going on. The heart of all these counseling sessions is the presence of students in the faculty room and enjoying the views of teachers on students' problems.

The use of cyberspace to benefit and greater access at all times of day and in the forum could set the stage for further communication of professors with students and for taking scientific profit from professors. Due to this, along with the mentioned advantages, the forums can be used alongside traditional learning to complete the students' learning. This process has dealt with evaluating the impact of teachers' forum to fill the role of Advisor and to improved access to teacher's services and links related to complement the classroom learning teacher and then assess students in a formative way. In a study that was carried out with the aim of using the forum for earning functional skills and acquiring meaningful motivation in psychology courses compared to traditional teaching, the results showed that the use of the forum, along with promoting meaningful learning, enhances students' average scores. ${ }^{910}$. The results of another research on the use of forum in language education showed that these students were able to study source books and completed their assignments more carefully ${ }^{11}$. Other research has also shown that the use of discussion boards provide the groundwork for greater progress compared to other methods. Such students penetrate to the heart of issues and the culture of scientific work faster than their peers. The role of cultural environment created in the interaction with the online learning is among those factors that can be more helpful in gauging students' progress than the individual performance in working with these systems ${ }^{12}$. Promoting students' writing style through blogs and forums and fun learning are of other features of using online learning in some research in which online learning in the form of blended learning has been used to complete foreign language proficiency ${ }^{13}$. Participants' more engagement and more equality of participants in the interaction have been expressed other benefits of using forums ${ }^{14}$. In a further analysis, foreign language learners have shown their understanding of the Forum with $70 \%$ improvement in their writing skills ${ }^{15}$. Being located in the interaction network pave the path for students to engage more with the content and learn more from their peers ${ }^{16}$. Little research has been done on this subject in Iran. The only study in this field was carried out in Virtual School of Tehran University in which: The results showed that the use of electronic forums in academic learning management system, along with strengthening topic learning, fortifies high levels of cognitive skills and social capabilities such as how to communicate with others and how to negotiate as well as improving research and writing skills in students. However from the vantage point of teachers, forums do not have any impact on the development of cognitive skills, topic learning and collaborative competence.

Method: In this study, a forum was used for the development of virtual learning. This space is to use for problem-based learning, expressing scenarios related to the lesson. Online quizzes were developed by designing problem-based and divergent questions and group discussion around it. And then it continued through being promoted with a virtual round for the participation of all groups of students and the engagement of professors of different groups. This subject was designed and developed with the aim of scientific reflection for students and faculty.

Virtual round of different groups:

\section{Results:}

- Creating the culture of using virtual networks among teachers in training

- Efficient use of virtual facilities to complement students' learning through problem-based learning

- Rethinking or reflection (Reflection)

- promoting students' group and practical interaction in a virtual environment

- Promoting the culture of problem-based learning in teachers

- Enhancing collaborative learning through online evaluation

- Upgrading computer literacy in students

- Transferring students' attitude in an academic atmosphere and increasing student's constructive criticism of teachers by facilitating the process in cyberspace

- Acceptable participation of students in academic interactions 

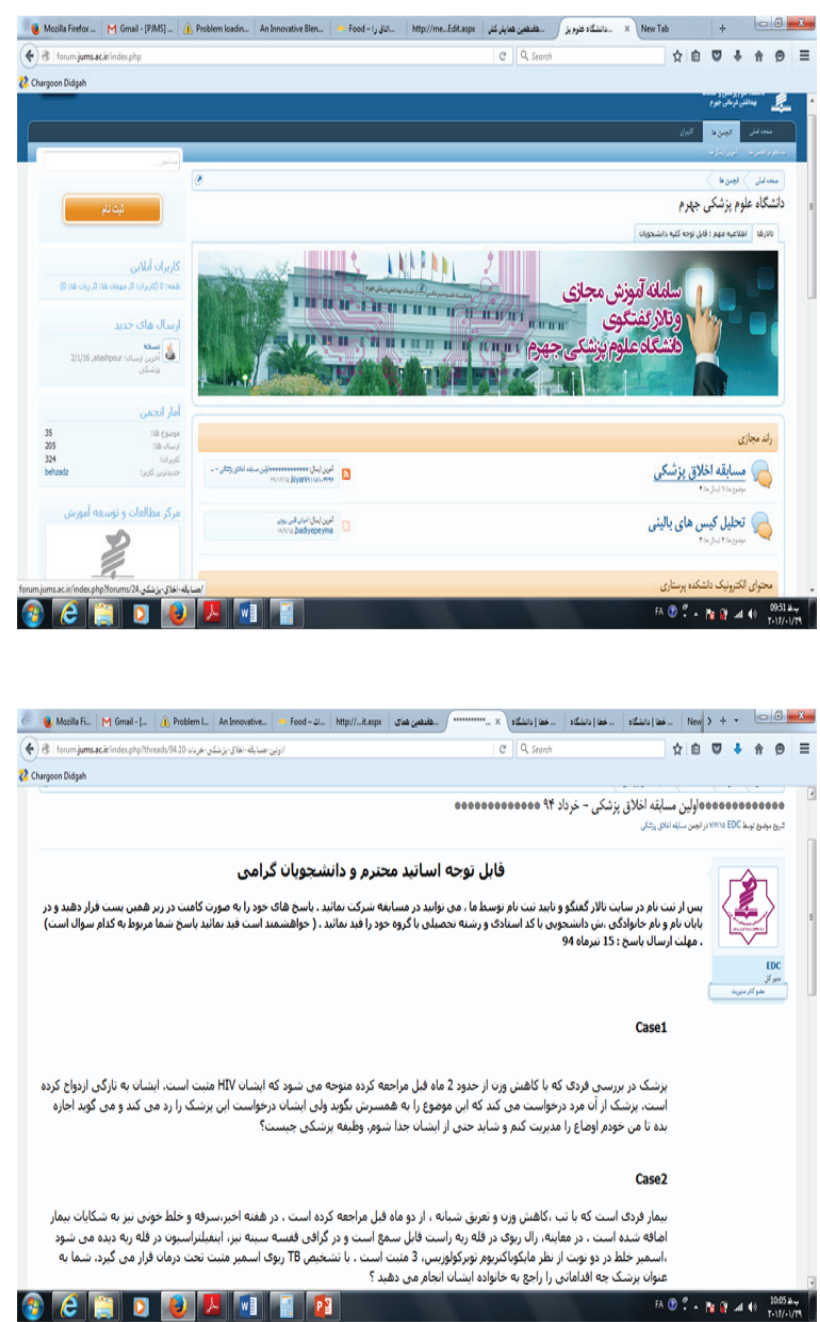

Online quizzes for nursing students:

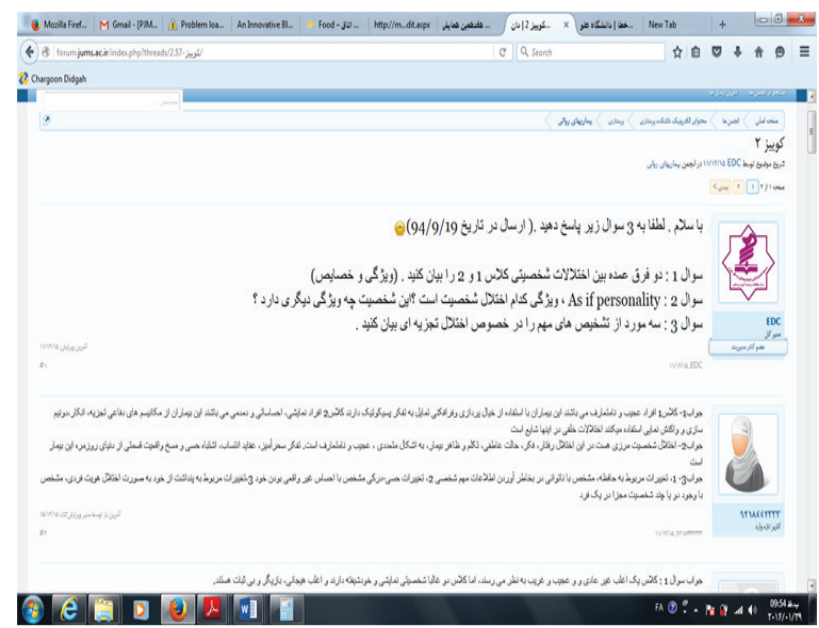

Scenarios of psychiatric lessons for nursing students:

Other Results: Out of 90 students and 8 teachers using the forum to teach problem-based and virtual round. Analysis results showed that most people express optimum satisfaction with using group discussion (Forum) to learn. The number of visitors

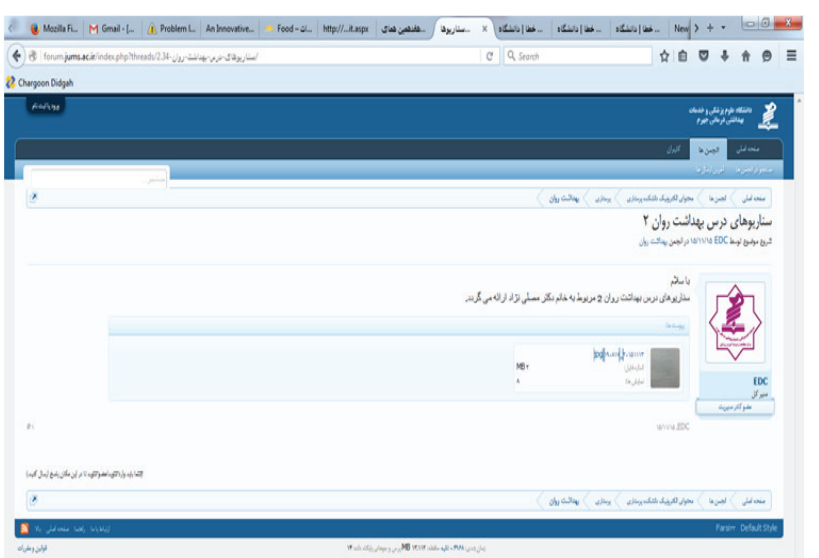

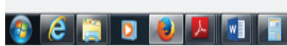

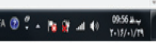

Scenarios of infectious block for medical students
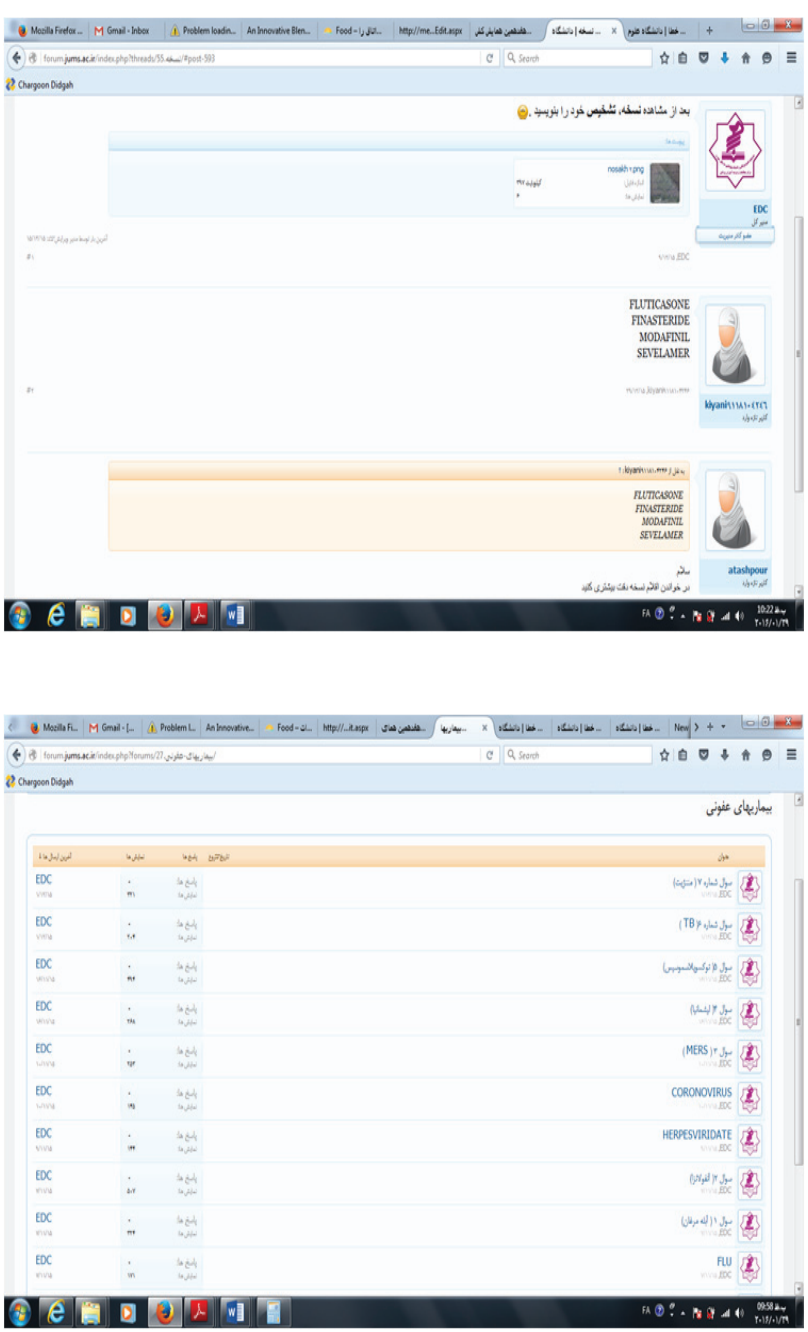

Clinical pharmacology course's scenarios:

and users, also, showed that during this period, 1,200 comments were attached by the students in this section which shows the strong interest of students to the mentioned methods and to other technologybased teaching methods. 
Table 1: The results of students and tutors' attitude toward problem solving base learning in forum

\begin{tabular}{|c|c|c|c|}
\hline $\begin{array}{l}\text { Disagree } \\
\quad \%\end{array}$ & $\begin{array}{c}\text { Nutral } \\
\%\end{array}$ & $\begin{array}{l}\text { Agree } \\
\%\end{array}$ & $\begin{array}{l}\text { State } \\
\mathbf{N}=90\end{array}$ \\
\hline 10 & 12 & 78 & $\begin{array}{l}\text { I consider the forum as a continuity of the } \\
\text { face-to-face traditional class }\end{array}$ \\
\hline 8 & 7 & 85 & $\begin{array}{l}\text { Use of forum helped me to deep } \\
\text { understanding of content }\end{array}$ \\
\hline 6 & 11 & 83 & $\begin{array}{l}\text { Use of forum helped me to more } \\
\text { communicate with teachers and peers in a } \\
\text { course }\end{array}$ \\
\hline 12 & 19 & 69 & $\begin{array}{l}\text { Use of forum helped me to focus on the } \\
\text { knowledge related to the learning objectives }\end{array}$ \\
\hline 8 & 21 & 71 & $\begin{array}{l}\text { Use of forum helped me to increases } \\
\text { problem solving skills in a clinical ward }\end{array}$ \\
\hline 7 & 8 & 85 & $\begin{array}{l}\text { Use of forum provided an effective group } \\
\text { learning environment }\end{array}$ \\
\hline 6 & 12 & 82 & $\begin{array}{l}\text { This approach integrate traditional learning to } \\
\text { new method of learning }\end{array}$ \\
\hline 12 & 16 & 72 & $\begin{array}{l}\text { Use of forum helped the students to } \\
\text { increases reflection in the self learning and } \\
\text { self directed learning }\end{array}$ \\
\hline 11 & 17 & 72 & $\begin{array}{l}\text { Use of forum helped students to increases } \\
\text { self reflection in learning }\end{array}$ \\
\hline 9 & 13 & 78 & $\begin{array}{l}\text { I enjoyed from this condition at the } \\
\text { classroom ( learning from peers) }\end{array}$ \\
\hline 8 & 6 & 92 & $\begin{array}{l}\text { I am satisfied with using the forum as group } \\
\text { learning }\end{array}$ \\
\hline 11 & 13 & 76 & $\begin{array}{l}\text { I look forward to learn using the online } \\
\text { discussion in the future learning }\end{array}$ \\
\hline 0 & 0 & 100 & $\begin{array}{l}\text { I was motivated to use the blended } \\
\text { learning(tutors ) }\end{array}$ \\
\hline
\end{tabular}

The preparation and presentation of virtual content and conducting online exams were well welcomed by the students and, apart from creating vitality by taking quizzes in a different manner, set the stage for learning in an interactive environment. Satisfaction of $90 \%$ of students with the forum proves their interest in the use of these practices in teaching and learning. Students' participation in online quizzes and their answers to questions related to some units' scenarios, sometimes up to 1,000 cases in an infectious block, was indicative of students' welcome to this novel method.

Discussion: The present study showed that the interactive environment of the forum accompanied by problem-based learning environment can have an important role on interaction and collaborative learning.

There is little similarity in the study of the traditional techniques of teaching and learning online. For example, social relationships take place between students in both methods. But in the online method, of communication and expression of views and access to resources are more likely.

The evidences clearly show that integration of online discussion with PBL increases participants' interactivity between the conventional PBL sessions as has seen by similar studies ${ }^{17-19}$.

The proper use of technology has the ability to change professors teaching methods and the way of access to their teaching resources. The amount and form of teachers' communication with each other and with students, as well as the communication between students can also improve $^{20}$ and it, also, causes the development of learning opportunities through different ways such that each person, according to their abilities and consistent with their speed in learning training materials, can control their learning process. Even if learning should take place among more students or among several universities, it will reduce costs.

AHMAD et al (2012) carried out a study to combine the two methods of problembased learning and online discussion forum on 130 students (91 males and 39 females) participating in the process. These courses were handled by 14 coaches each were assigned to a group. Having discussed the issue (in the form of text and comments) with students in virtual space, problem-solving forum was conducted online by trainers. Finally, the satisfaction of educators and students with the created intervention was evaluated. Obtained messages included: Improvement and finalizing learning objectives, developing motivation in each other and trainers' redirection 
and feedback. Most students believed that this combined method increased collaboration and intervention between the participants and enhanced the relationship between them and the trainers. On the other hand, trainers asserted that this combined method enhanced relations and cooperation between the students and between students and mentors. Most coaches agreed with holding such forums and called for such applications in the future ${ }^{21}$. The results of the study done by Sunčana KukoljaTaradi et al (2008), evaluating online selection courses among medical students with respect to virtual movements of students and national and virtual team collaboration, found that the majority of students had expressed their satisfaction with online selection courses for reasons such as: their more contact with their peers and coaches, better opportunity for self-assessment, more flexible learning, better access to learning resources, faster and easier information retrieval and better quality of communication between coaches and colleagues ${ }^{22}$. The expressed research results confirmed the results of the present research. Most students in the present study believed that this way of learning had an influence on self-regulated learning and on improving their ability to self-direction. In addition, group interactions provide a fertile ground for peer learning.

One of the salient features of meaningful interaction is the fact that a person's comments are being read. The learners' interaction with peers substantiates interpersonal support, backing and approval which are further proved by their answers and feedbacks ${ }^{20}$. A group commitment is developed and fortified by consistent responses ${ }^{23}$. Even in the absence of nonverbal hints such as facial expression and eye contact, the online milieu takes advantage of the ability to support highly emotional interactive relations ${ }^{24}$. Cutler explicates that "the more one discloses personal information, the more others will reciprocate, and the more individuals know about each other, the more likely they are to establish trust, seek support, and thus find satisfaction" ${ }^{25}$. The interactive involvement of the learner in attempting to come to and express their own appreciations of novel notions and concepts creates knowledge ${ }^{26-27}$. In order to 'come to know', learners are required to arrive at their own understanding of information and come to notions and perceptions through their peers' feedbacks and rejoinders. According to $\mathrm{Nichani}^{28}$, an online community will be successful if three fundamental criteria are met: the leader, the social contacts and the objective of the group. The responsibility of outlining the program for the discussion and dealing with interactions, which is considered organizational, lies with the moderators. The social aspect of their responsibility is to establish a cordial learning milieu and the intellectual dimension of their responsibility is to improve learning by asking relevant questions and then expounding points. The interpersonal interactions are deemed as the chief solidifying factor within the group ${ }^{29}$. Anderson and Elloumi (2004), parallel to many authors as Ally (2004), outlined the advantages of asynchronous interactions ${ }^{30-31}$. The appreciation of the magnitude of thinking about taught materials, the contextualized content and the use of information are widely believed to be consistent with the Jonassen's (2006) suggestion for the scheme of constructivist learning environments ${ }^{32}$. A wide-ranging variety of evaluation techniques, proposed by authors like Alley, Blocher and Markel (2005), can be encompassed into online education ${ }^{33}$. According to Mc Anally-Salas and Organista (2007) the extensive variety of selections and insights of teachers and authorities of the HEIs makes online education an intricate process that is highly liable to lead to confusion among its users. Evidently, it is the role of actors in discussion process to build up the notion of online education on the basis of its forms and its foundation ${ }^{34}$. This absence of unanimity on the nature of online education between the scholars and involved academics could account for the wide range of the appreciations among university authorities of what Van der Klink and Jochems (2004, p. 151) considered as "high-level ambitions with poor instrumentation". Conventionally, at organizational level, specific departments or training centers are entitled with training teachers with the aim of combining online learning with their instructional practices ${ }^{35}$.

Forums, in the present study, have been used to complete learning and design problem-based learning and its results have been studied by numerous researches and had numerous benefits.

According to De Leng et al. (2006), incorporating online forum into traditional PBL assists students working out operative learning resources. This also enhances availability and flexibility which provide all learners with a constructive learning milieu ${ }^{36-37}$. Medical education literature has casted little attention to incorporating forms into PBL. A study carried out by Ronteltap and Eurelings (2002) on third- and fourth-year medical students in the Netherlands deals with the students going through a radical change in their learning experience, accordingly, 
their discussions getting more intense and their learning more profound ${ }^{38}$. Again in the Netherlands, De Leng et al. (2006) revealed that students highly appreciated the information received from their peers in online discussions, and came to conclusion that some were frustrated by the scarcity of comments ${ }^{39}$. Being faced with a problem, an assisted group outlines their own learning perspectives, looks for them through autonomous self-directed study, and then rearranges to discuss and upgrade their knowledge (Azer2007; Wood 2008) ${ }^{40-41}$. In the course of this process, they cultivate skills in pondering, critical assessment, self-governing, group working and social interaction ${ }^{42-43}$. Instructors can also think of a question and create better and more comprehensive answers ${ }^{44}$. The main advantages of DFs are improving the interaction of students with peers and that of student with tutors as well as enhancing contact time ${ }^{45-46}$. Students' questions and doubts can be cleared up prior to the last PBL session ${ }^{47}$, and constant comments can be offered to the students at regular intervals from PBL group members and their tutors as well ${ }^{48}$.

The expressed results corroborated the students' statements regarding the effectiveness of teaching methods and were indicative of our research results about the individual and group effects of this type of learning.

During the study carried out by Kuo et al. (2006) to develop and evaluate web-based wound care courses on nursing students, most students expressed their satisfaction with the content of taught material and their application ${ }^{49}$. Also in the present study, the students were satisfied with using the forum for complementary and problem-based learning and pointed out its impact on practical learning and welcomed this application of technology in teaching and learning practices.

\section{Conclusion:}

However, in order to integrate education in Medical Sciences and stabilize it for long-term use, all the people contributing in the promotion of the quality of education, such as (students, policy makers and teachers), are required to recognize the performance of these technologies inevitable, make an effort to improve its quality and use it in education more than ever. We believe that taking advantage of online forums as a virtual technology, apart from being available at any time and in any place, can also enhance cooperation between members of groups, their desire to work together, increase the quality of the exchanged content and eventually lead to stabilized learning in students. 


\section{References:}

1. WALLACE R. (2003) .Online learning in Higher Education: a review of research on interactions among teachers and students. Education, Communication \& Information. 3,2. DOI: 10.1080 / 14636310303143

2. http: //elearner.blogfa.com/post-120.aspx

3. Simpson A, Reynolds L, Ian Light I, Attenborough J. (2008). Talking with the experts: Evaluation of an online discussion forum involving mental health service users in the education of mental health nursing students. nurse education today. 28, 5: Pages 633-640.

4. Merriam-Webster (2006). Blog defined by the beginners guide staff. Retrieved October 7, 2006, from http:// beginnersguide.com/blogs/what-is-a-blog/blog-defined.php

5. Merriam-Webster (2006). Blog history by the beginners guide staff. Retrieved October 7, 2006, from http:// beginnersguide.com/blogs/what-is-a-blog/blog-history.php

6. Martindale, T. \& Wiley, D. (2005). Using weblogs in scholarship and teaching. TechTrends, 49 (2), 55-61.

7. Ray, J. (2006). Welcome to the Blogosphere: The Educational Use of Blogs (aka Edublogs). Kappa Delta Pi Record, 42 (4), 175-177.

8. Richardson, W. (2005). Blog revoluation: Expanding classroom horizons with web logs. Technology \& Learning (25 (3), 48.

9. http: //www.behdasht.gov.ir/

10. Marion A. Epplera. FACULTY FORUM: Mastery Learning Benefits Low-Aptitude Students. Teaching of Psychology, 2007; 34 (1): 28-31

11. Hanna BE. Nooy JD. A FUNNY THING HAPPENED ON THE WAY TO THE FORUM: ELECTRONIC DISCUSSION AND FOREIGN LANGUAGE LEARNING. Language Learning \&Technology.January 2003; 7 (1): 71-85.

12. De Nooy, Juliana. and Hanna, Barbara E. (2003) A funny thing happened on the way to the forum: Electronic discussion and foreign language learning. Language, Learning and Technology, 7 1: 71-85.

13. Miyazoe T, Anderson T. Erratum to "Learning outcomes and students' perceptions of online writing: Simultaneous implementation of a forum, blog, and wiki in an EFL blended learning setting" [System 38 (2010) 185-199] • System, 38 (3): Page 515.

14. Fitze (2006). Discourse and participation in ESL faceto-face and written electronic conferences Language Learning \& Technology, 2006; 10 (1):. 67-86 Retrieved from: http://lit.msu.edu/vol10num1/pdf/fitze.pdf

15. Kol, M, Schcolni k. Asynchronous forums in EAP: assessment issues. Language Learning \& Technology, 12 (2) (2008), pp. 49-70

16. Retrieved from: http: //llt.msu.edu/vol12num2/ kolschcolnik.pdf16-Sara Kol S, Schcolnik M. A synchronous forums in EAP: Assesment issues. Language Learning \& Technology http://llt.msu.edu/vol 12num2 / kolschcolnik / June 2008; 12 (2).

17. Cheaney JD. $2006 . \quad$ Problem-based learning in an online course: A case study. Int Rev Res Open Dist Learn 6: 1-18

18. Taradi SK, Taradi M, Radic K, Pokrajac N. 2005. Blending problem-based learning with Web technology positively impacts student learning outcomes in acid-base physiology. AdvPhysiolEduc 29: 35-39.

19. Woltering V, Herrler A, Spitzer K, Spreckelsen C. 2009. Blended learning positively affects students satisfaction and the role of the tutor in the problem-based learning process: Results of a mixed-method evaluation. Adv Health SciEduc 14: 725-738.

20. Tao Sun et al. Participation Maximization Based on Social Influence in Online Discussion Forums. Conference: Proceedings of the Fifth International Conference on Weblogs and Social Media, Barcelona, Catalonia, Spain, July 17-21, 2011

21. A. S. Alamro\& S. Schofield. Supporting traditional PBL with online discussion forums: A study from Qassim Medical School. Med Teach. 2012; 34 Suppl 1: S20-4. doi: 10.3109 / 0142159X.2012.656751.

22. Taradi et al. Scaling-up Undergraduate Medical Education: Enabling Virtual Mobility by Online Elective Courses. Croat Med J 2008; 49: 344351.

23. Bagherian F, Thorngate W. Horses to Water: Student use of course Newsgroups. First Monday. 2000; 5 (8). Retrieved November 20, 2009, from http://firstmonday.org/htbin/cgiwrap/bin/ojs/index. $\mathrm{php} / \mathrm{fm} /$ article/view/779/688

24. Eggins S, Slade D. Analyzing casual conversation. Washington, DC: Cassell; 1997.

25. Angeli C, Bonk C, Hara N. (1998). Content analysis of online discussion in an applied educational psychology course Online. CRLT Technical Report No. 2-98; 1998. Retrieved November 20, 2009, from http://crlt.indiana. edu/publications/crlt98-2.pdf.

26. Cutler R. (1995) Distributed presence and community in Cyberspace. Interpersonal Computing and Technology: An Electronic Journal for the 21st Century. 1995; 3 (2): 12-32.

27. Jonassen DH, Duffy TM, Lowyck J. (eds) Designing environments for constructive learning. NATO ASI Series, Series F: Computer and Systems Sciences, Vol 105. Heidelberg, Germany: Springer-Verlag; 1993.

28. Laurillard D. Rethinking university teaching: A framework for the effective use of educational technology. London: Routledge; 1993.

29. Nichani MR. Learning through social interactions (Online communities). Elearningpost.com. 2000. Retrieved November 20, 2009, from http://www. elearningpost.com/images/uploads/comm.pdf.

30. Anderson, T., \&Elloumi, F. (2004). Theory and practice of online learning. Athabasca, AB: Athabasca University. 
Optimal Use of the Forum to Develop Problem-Based Learning: Effective Use of Cyber space in a Holistic Process

Retrieved from http://cde.athabascau.ca/online_book/

31. Ally, M. (2004). Foundations of educational theory for online learning. In Theory and practice of online learning (pp. 3-31). Athabasca, AB: Athabasca University. Retrieved from http://cde.athabascau.ca/online_book/ FORMTEXT.

32. Jonassen, D. (2006). Welcome to the design of constructivist learning environments (CLEs). Retrieved from http://tiger.coe.missouri.edu/ jonassen/courses/ CLE/main.html; http://tiger.coe.missouri.edu/ jonassen/ courses/CLE/.

33. Alley, P., Blocher, M., \& Markel, S. (2005). The road to assessment: An examination of one college's systematic process for evaluating electronic portfolio software. In Society for Information Technology \& Teacher Education International Conference (pp. 12-13). Charlottesville, VA: Association for the Advancement of Computing in Education (AACE). Retrieved from http://www.editlib.org/index.cfm?fuseaction=Reader. ViewAbstract\&paper_id=18938.

34. McAnally-Salas, L. (2007). Contextual factors that influence teacher training in the design of online courses. (Doctoral dissertation, Universidad Autónoma de Tamaulipas). Retrieved from http://148.231.200.29/ blogs/mcanally/12/tesis- files / 2007 / doctoral-mcanally. pdf

35. Jonassen, D. (2006). Welcome to the design of constructivist learning environments (CLEs). Retrieved from http://tiger.coe.missouri. edu/ jonassen/courses/CLE/main.html; http:// tiger.coe.missouri.edu/ jonassen/courses/CLE/ Kjhd [

36. Garnham C, Kaleta R. 2002. Introduction to hybrid courses. Teach Technol Today 8 (March): 8.

37. Gould T. 2003. Hybrid classes: Maximizing institutional resources and student learning. In: Proceedings of the 2003 ASCUE Conference, 2003 June 8-12. Myrtle Beach, SC.

38. Ronteltap F, Eurelings A. 2002. Activity and interaction of students in an electronic learning environment for problem-based learning. DistEduc 23: 11-22.

39. de Leng BA, Dolmans DHJM, Muijtjens AMM, van der Vleuten CP. 2006. Student perceptions of a virtual learning environment for a problembased learning undergraduate medical curriculum. Med Educ 40: 568575 .
40. Wood D. 2008. Problem based learning: Time to stop arguing about the process and examine the outcomes. BMJ 336: 971-971.

41. Azer S. 2007. Navigating problembased learning. Sydney, Australia: Elsevier.

42. Taylor D, Miflin B. 2008. Problembased learning: Where are we now? Med Teach 30: 742-763.

43. Dodd L. 2007. The impact of problem-based learning on the information behavior and literacy of veterinary medicine students at University College Dublin. J Acad Librarianship 33: 206-216. Dunkel P, Mishra S, Berliner D. 1989. Effects of note taking,

44. Meyer K. 2003. Face-to-face versus threaded discussions: The role of time and higher-order thinking. JALN 7: 55-65.

45. Klimova B. 2009. Blended learning. In: Research, reflections and innovations in integrating ICT in education. Vol. 2. Spain: Formatex. pp 705-708 [Internet]. Available from: http://www.formatex.org/ micte2009 / book / 705-708.pdf.

46. Adesope T, Adesope O, Ojeme C. 2008. Traditional and online forms of education: Proposing a common ground. In: Bonk CJ, Lee MM, Reynolds T, editors. Proceedings of the world conference on e-learning in corporate, government, healthcare, and higher education, 2008. November 17-21. Las Vegas, NV, USA, Chesapeake, VA: AACE. pp 2071-2076.

47. Sharpe R. 2006. Why blend? Rationales for blended e-learning in undergraduate education [Internet] Briefing Paper. York: The Higher Education Academy. Available from: http://www.heacademy.ac.uk/ assets / documents / archive / blended_elearning_why_ blend.pdf.

48. Alamro A. 2010. Blended problem-based learning: Using technology to overcome face-to-face drawbacks and enhance PBL advantages at Qassim Medical School, Saudi Arabia. Dundee: Center for Medical Education, University of Dundee.

49. Koetal.Development and Evaluation of the Webbased Wound Care Course for Undergraduate Nursing Students. Journal of Korean Academy of Nursing Vol. 36 , No. 8 